Tarih Kültür ve Sanat Araştırmaları Dergisi

Revue des Recherches en Histoire Culture et Art مجلة البحوث التاريخية والثقافية والفنية
Vol. 7, No. 4, November 2018

Copyright (C) Karabuk University http://kutaksam.karabuk.edu.tr

\title{
DOI: 10.7596/taksad.v7i4.1801
}

Citation: Fazliev, A., Shakurov, F., Minnullin, Z., \& Nafikov, I. (2018). Public Organizations of Tatar Students in the Ottoman Empire in the Beginning of 20th Century. Journal of History Culture and Art Research, 7(4), 16-22. doi:http://dx.doi.org/10.7596/taksad.v7i4.1801

\section{Public Organizations of Tatar Students in the Ottoman Empire in the Beginning of 20th Century}

\author{
Aivaz Fazliev', Farit Shakurov², \\ Zavdat Minnullin ${ }^{3}$, Ilsur Nafikov ${ }^{4}$
}

\begin{abstract}
Impetuous and turbulent flow of the national life of the Tatars in the late XIX - early XX centuries are traditionally associated with the formation of an ethnic community of a new national type and the turning points of world history. The paper presents the first experience of the systematization of information on public organizations of Russian Tatar students in the Ottoman Empire in the early twentieth century. The study is based on the materials of a valuable, little-researched source - the Tatar periodical press of that time. Organization of youth societies abroad is considered as part of the process of the emergence and development of charitable and other associations representing elements of civil society. Along with the Istanbul societies mentioned in the literature, the organizations of young people in Cairo, Mecca, Medina and Beirut are identified, as far as the sources and content and nature of their activities allowed. The documents illustrating the attempts of state structures to resist the training of Muslim youth abroad and their interest in the activities of the respective societies are given. The role of foreign charitable societies and compatriots of Tatar students as a special social institution has been determined. The findings, the factual material of the paper can be used to write general and special works on the history of Turkey, Russia and Tatarstan, the Tatars and other Turkic peoples.
\end{abstract}

Keywords: History, Islamic studies, Muslims of the Russian and Ottoman empires, Public organizations and associations, Charitable societies, Tatar student youth, Education abroad, Censorship.

\footnotetext{
${ }^{1} \mathrm{PhD}$ in History, associate professor, Department of National History, Institute of International Relations, Kazan Federal University, Kremliovskaya str., 18, 420008, Kazan, Russian Federation. E-mail: aivazik@mail.ru ${ }^{2} \mathrm{PhD}$ in History, associate professor, Department of National History, Institute of International Relations, Kazan Federal University, Kremliovskaya str., 18, 420008, Kazan, Russian Federation, FNShakurov@kpfu.ru

${ }^{3} \mathrm{PhD}$ in History, associate professor, Department of regional studies and Euroasian research, Institute of International Relations, Kazan Federal University, Kremliovskaya str., 18, 420008, Kazan, Russian Federation, zminnullin@mail.ru

4 PhD in History, Kazan Federal University, Kremliovskaya str., 18, 420008, Kazan, Russian Federation, global@ores.su
} 


\section{INTRODUCTION}

Traditional centers of education for Tatar youths for a long time were Bukhara, Samarkand and other centers of Muslim scholarship in Central Asia. Since the middle of the nineteenth century, Bukhara madrasah, stagnant in the Middle Ages, begin to lose their authority and attract less and less young people seeking answers to the challenges of time in Islam, or, moreover, wishing to receive secular knowledge in demand by the realities of the century.

The founder of the Tatar reform and educational movement, Sh. Mardzhani (1818-1889), wrote: "For the future of our people, rescuing it from eternal oppression in the arena of life, we need European knowledge, education, culture and industry. Knowledge and enlightenment can be provided wherever they are. They do not know any national or language boundaries" [1]. One of his favorite students Kh. Faizkhanov broke age-old traditions and chose St. Petersburg to improve his knowledge. Toward the end of the nineteenth century, more and more Tatar youth learns not only in Russian gymnasiums and universities, but also in educational institutions of Western Europe. The following remarkable fact describes the extent of the desire to gain knowledge abroad. In 1912, a note was published on the pages of the newspaper "Vakyt" (Time) about a student in San Francisco, Kh. Baibulatov. He received many letters with requests to talk about the rules of enrollment and living conditions and, unable to answer each one individually, came up with explanations in the press [2].

However, the enrollment in Russian and European educational institutions was arranged with the requirements and conditions that made it unlikely for the Tatar Shakirds of yesterday. Education in the Ottoman Empire was more accessible and was not limited to numerous traditional madrasah. Newly opened schools and colleges offered a modern education system and quality knowledge. It should also be taken into account that the public mind of the Tatars has a well-disposed attitude towards Turkey. Relations with it continued even after losing independence, supported by hajj. Departure to the Ottoman Empire to the educational centers of Turkey, Arabia, Egypt or Lebanon did not seem to be associated with insurmountable difficulties and deprivations.

The growth of the number of Tatar youth, going for knowledge to distant countries, has put on the agenda the issue of organizational and material support of this process. In the public debate, it is clearly stated that the first condition for achieving the urgent task of "getting a new education" is the organization of societies for the help of young students [3]. Emerging communities and mutual aid societies were nothing more than forms of self-organization - elements of civil society, which development remains today an urgent task.

\section{MATERIALS AND METHODS}

The methodological basis of the study was the principle of historicism. In combination with general scientific methods, such as analysis and synthesis, special historical methods (historical-genetic, comparative-historical, historical-typological), as well as a statistical method, were used to write the paper.

The most important is the use of a system-structural approach in this study that allows for the representation of public organizations of Tatar students in the context of the public and political life of the Ottoman Empire. System-structural analysis is the methodological basis for the study of public institutions. The use of an integrated approach makes it possible to study the diversity of public, student and Muslim organizations as a single complex. The use of the historical-anthropological approach is due to the fact that the focus of attention was on the youth Tatar movement, as a community with a certain self- 
awareness. The application of a functional approach is necessary to consider the forms and methods of work of student organizations for the preservation and development of Islamic cultural traditions.

During the research, such concrete historical methods as the method of critical source analysis and historical and biographical methods were also used. The nature of the tasks set in the work determined the need to apply, in addition to general scientific, special historical methods: comparative historical, logical, analysis and synthesis, problem-chronological, reconstructive, complex and critical approach to sources and historiography on the topic. The integrated application of these methods allowed the authors to identify the general and the particular, to structure the individual elements of the phenomenon under study into a system, to make conclusions and generalizations.

\section{RESULTS}

In the late XIX and early XX centuries, changes took place in the public life of the Tatars, deserving close attention. The internal law of the ummah - the social needs are the concern of the whole community - is extrapolated and begins to be reflected by the whole nation. Charitable and public associations and organizations arise and develop. Traditions stemming from the requirements of Islam, become the basis for the formation of elements of civil society. The organization of the Tatar youth societies abroad of the empire should be considered in the mainstream of this process.

By 1917, every major settlement where Tatars lived compactly had charitable societies. The total number of them according to our preliminary calculations reached up to three hundred. Their funds consisted of membership fees, donations, targeted fees, income from real estate. Unlike the Orthodox parish societies, the Tatar societies also used secular means of raising funds: the organization of charity performances and concerts, literary and musical evenings, cinematographic sessions, the Sabantuy national holiday and other events [4]. By their activity, they can be conditionally divided into general, female and special. They included special societies for the provision of assistance to students, for example, opened in 1912 in Orenburg on the initiative of a gold miner and philanthropist, a classic of Tatar poetry Z. Rameev (Derdmend). It is known that students studying abroad, for example, in the Muslim East, as well as in Europe and America, applied to him [5]. However, according to the charter and the requirements, the scope of his activities was limited to the borders of the Russian Empire.

The first known society of the Tatar youth, the "Society of Turkic-Tatar Disciples", was established in early 1906 in Cairo by the shakirds of the Orenburg madrasah "Khusainia", sent to study with merchant M. Khusainov's money [6]. According to some reports, leaked to the press, Tatar students of the largest Islamic university "al-Azkhar" among the ten thousand Taliban were considered the most informed and intellectually developed. Members of the society actively participated in the discussion of the problems of school education of the Tatar Muslims of Russia, which one day calmed down, and another day intensified constantly on the pages of the periodical press [7].

"Society of Russian Muslim Students", which arose in 1908 in Istanbul, united the Volga and Crimean Tatars [8]. In the same year, another society was established to assist the Tatar shakirds. In 1912 they merged, uniting about 70 students. The honorary trustee of a single society was the Istanbul businessman I. Gabdushev. The adopted program of activities, in addition to the organization of material assistance, provided the members with literary novelties, newspapers and magazines. Being the largest foreign Tatar youth organization, the society had its own club with a reading room, where musical evenings, meetings with representatives of the Turkish and Russian publics were arranged [9]. Socio-political events and urgent problems of renewal, for example, the women's issue, were discussed the meetings. It assisted in enrolling in educational institutions and providing cheap housing. The leadership of the society took steps to regulate the process of teaching the Tatars in the Ottoman Empire, trying to guide those who 
arrived to deepen knowledge in the field of Islamic studies in the educational institutions of Mecca, Medina, Cairo, and leaving in Turkey those who wished to get secular education (proceeding from what is better) [10].

"Scientific Society of Russian Islamic students" in Mecca was established in 1909 [11]. The work was built on the basis of the charter program approved by the Mecca authorities, which detailed the structure, activities and membership issues in detail. The society, called "scientific", was essentially a land association of charitable character. Like other student societies, it set the task of creating a library. The program talked about the need to establish links with other organizations of Tatar students.

In March 1909 the statute of the "Scientific Society of the Kazan Taliban in the Medina" was adopted, almost repeating the rules of the Meccan "Scientific Society" [12]. Declaring that it does not pursue political goals, it set the task of providing moral and material support to students, strengthening patriotic and national feelings, training educated people who after returning to their homeland will teach people useful knowledge. Turkish researcher Arzu Kılınç reports on the establishment of a "Society of Kazan Students" in Taif, Arabia [13].

In 1914, the Tartar students at the American College in Beirut, following the example of Jewish, Armenian and other classmates, decided to organize the "Tatar Library" in order to keep abreast of literary novelties and to acquaint their comrades and teachers with Tatar literature [14]. According to the established tradition during the holidays in the college, evenings were organized where representatives of different nationalities spoke on certain topics and recited poems in their native language. American missionaries used these evenings to promote Christianity. During such disputes, the Shakirds managed to refute (as they claimed) many of their positions, relying on the works of the Tatar theologian M. Bigiev. Addressing the public through the newspaper "Vakyt", they asked to send novelties of Tatar literature, as well as newspapers and magazines in their native language.

Representatives of Russian conservatism found undesirable everything that could contribute to "isolation of the Muslim population of Russia", including "mutual aid societies and special charitable societies and reading rooms" [15]. The lecturer of the Kazan Theological Academy, the censor of the Kazan Press Committee P. Zhuze, on March 6, 1914, shared with the Kazan governor his views on "foreign influences on Muslims", with the demand to prohibit the Tatars from traveling to study in the educational institutions of the Ottoman Empire, "because, perhaps, they speak there against us" [16]. In March 1901, G. Gafurov's manuscript "Whose hands hold the Tatar language and when it will be improved" was not allowed for printing because of the call to study in Germany and the American colleges of Beirut [17].

Information about the life of Russian Muslim students in the Ottoman Empire and the activities of their societies is presented in the report of an officer of the Department of Spiritual Affairs of Foreign Religions of the Ministry of Internal Affairs, who was sent to Cairo and Istanbul in 1912 [18]. In 1914, the Kazan Provincial Gendarmerie Department sent a secret agent called "Theoretician" Kh. Kaibyshev to Istanbul, who met with activists of the Istanbul and medical societies of Tatar students [19].

\section{DISCUSSIONS}

The development of relations between the Tatars of the Russian Empire and Turkey at the end of the XIX and the beginning of the XX century and the changes in their traditional content are considered by modern researchers primarily in the most well-known aspect - the role of the Turkic intellectuals of Russia in the ideological and political life of the Ottoman Empire in the era of the Young Turks, underscoring the inextricable link between the ideas of Turkism with Tatar Jadidism [20]. In A. Sibgatullina's monograph the first special work devoted to the contacts of the Turk-Muslims of the Russian and Ottoman empires at 
the turn of the century - an attempt was made to highlight a number of aspects of this multifaceted topic [21]. The author dwells on the issues of organizing the pilgrimage of Russian Muslims, analyzes the coverage of events in Turkey by the Muslim press of Russia, talks about the trips of prominent Turkish public figures to Russia, a separate chapter is dedicated to the Turkish prisoners of the First World War. The book provides brief information about the activities of the Istanbul societies of Russian Muslim students. The chosen problem has not been specifically and thoroughly considered in the literature, including within the framework of studying the history of public associations and organizations. The interrelations of the Muslims of Russia and Turkey have become increasingly close; they are only partially indicated and are waiting for their researcher [22].

\section{CONCLUSION}

The received knowledge became a basis of successful professional activity of graduates on their return home. For example, the secretary of the "Society of Turkic-Tatar Disciples" in Cairo, S. Bikbulatov, after completing a course in "Al-Azkhar", begins teaching in the Orenburg "Khusainia" madrasah. He is the author of the monograph "Four Caliphs", which, in terms of the sources involved and the depth of the elaboration, was considered the best work on the history of Islam [23]. He also compiled a textbook of the Arabic language, which was repeatedly reprinted after 1917 [24].

Study in foreign countries expanded the horizons of Tatar youths, acquainted them with the basics of socio-political and ideological doctrines that played a role in their formation as adherents of the reformation. Overseas societies and associations helped to streamline and effectively organize material support for students. They became a social institution that ensured the implementation of mutual assistance and communication with the Motherland, which developed social initiative and responsibility. Public organizations of shakirds recreated the atmosphere of their native cultural environment and promoted the Tatar culture.

\section{CONFLICT OF INTERESTS}

The authors declare that the provided information has no conflicts of interest.

\section{ACKNOWLEDGEMENTS}

The work is performed according to the Russian Government Program of Competitive Growth of Kazan Federal University.

\section{FOOTNOTES}

[1] Мәржани: Тууына 100 ел тулу мөнәсәбәте илә. Казан, 1916. Б.528.

[2] Америкадан мәктүб // Вакыт. 1912. 9 март.

[3] Бигиев М. Әдәбияты гарәбия илә голуме исламия. Казан, [1910]. Б.39-40.

[4] Minnullin Z.S. From the history of the Tatar charity societies of the late nineteenth and early twentieth centuries. // Tatarstan. 1995. No.11/12. p. 23-27.

[5] «Укучыларга ярдәм жәмгыяте» тарафыннан // Вакыт. 1913. 9 ноябрь.

[6] Мисырда татар таләбәсе жәмгыяте // Казан мөхбире. 1906. 9 апрель; [Мисыр шәһәрендә...] // Вакыт. 1906. 20 июнь. 
[7] Мисыр әл-Каһирәдә әл-Әзһәр // Шура. 1908. №. 4. Б.114-116.

[8] Истанбулда русияле татар шәкертләре // Йолдыз. 1908. 7 декабрь.

[9] Кәрими Ф. Истанбул мәктүбләре. Orenburg 1913. Б.413-414.

[10] Насыйри 3. Төркиядә укучы татар шәкертләре // Вакыт. 1914. 27 июль.

[11] Мәккәи мөкәррәмәдә (русияле ислам таләбәсенең жәмгыяте гыйльмиясе) // Шура. 1910. №. 6. Б.191-192.

[12] Мәдинәи мөнәүвәрәдә Казанлы таләбәсенең жәмгыяте гыйльмиясе // Йолдыз. 1909. 8 сентябрь.

[13] Kılınç, Arzu (2017). Situation of Russian, Turkish and Volga-Ural Tatars in the Middle East on the eve of the First World War // Peoples of the Volga and Ural regions between revolutions (1905-1917): Collection of scientific papers. Kazan.

[14] Бәйрутта татар таләбәсе // Вакыт. 1914. 22 гыйнвар; Бәйрутта татар таләбәсе // Тәржеман. 1914. 29 гыйнвар.

[15] Ostroumov N.N. The Koran and progress. Tashkent, 1901. p. 246.

[16] Karimullin A.G. Tatar book of the beginning of the twentieth century. Kazan: Tatar publishing house, 1974. p. 221.

[17[ Ibid., p. 190.

[18] A report by P. Antaki, a collegiate secretary attached to the Ministry of Internal Affairs, about his trip to Cairo and Constantinople. - RGIA, f.821, op.133, d.629, I.65.

[19] Мансуров Г. Татар провокаторлары. М., 1927. Б.28-38.

[20] Georges F. Turkic intellectuals of Russia in the Ottoman Empire and their influence in the Age of the Young Turks // Islam in the Tatar World: History and Modernity. Kazan, 1997. p.191-197; Mukhammetdinov R.F. Origin and evolution of Turkism. Kazan: Zaman, 1996. p. 272.

[21] A.T. Sibgatullina. Contacts of Turkic Muslims of the Russian and Ottoman empires at the turn of the XIX-XX centuries. Moscow: Institute of Oriental Studies, Russian Academy of Sciences, 2010. p. 264.

[22] Akhunov A. "Tatar real estate" in the East // Echo of the centuries = Гасырлар авазы. 2002. No.3/4. p. 79-84; Gainetdinov M. Such a far Middle East // Echo of the centuries = Гасырлар авазы. 1996. No.1/2. p. 117.

[23] Бикбулатов С. Дүрт хәлифә. әбү-Бәкер вә Гөмәр дәверләре. 1 жөзье. Казан, 1918.

[24] Мөбдәэлкыйраәт. Казан: Мәгариф, 1918. 1жөзье, 6 басма. 80 б; 2 жөзье, 3 басма. 906.

\section{REFERENCES}

Achunov, A. (2002). "Tatar real estate" in the East. The Echo of the centuries. No. 3/4. P. 79-84;

Gainetdinov, M. (1996). Such far middle East. Echo of centuries=Gasyrlar avazy. No. 1/2. P. 117.

Bagiev, M. (1910). Arabic and Islamic literature. Kazan, 39-40.

Bikbulatov, S. (1918). The Fourth Muslim. The era of the caliphs of Abu Bakr and Omar. Part 1. Kazan. 
Georges, F. (1997). Türkic intellectuals of Russia in the Ottoman Empire and their influence in the era of the young Turks. Islam in the Tatar world: history and modernity. Kazan, p. 191-197;

Initial course of reading the Koran (1918). Kazan: Enlightenment, Part 1, 6th edition. 80 p.; part 2, 3rd edition. $90 \mathrm{p}$.

Karelian schools (1913). Orenburg. 413-414.

Karimullin, G. (1974). Tatar book of the early twentieth century. Kazan: Tatar. kN. publishing house; 221.

Kylynch, Arzu (2017). The position of the Russian, Turkish and Volga-Ural Tatars in the middle East on the eve of the First world war. the Peoples of the Volga and Ural regions between revolutions (1905-1917): Sat. articles. Kazan; 265.

Madrasah "Al-Azhar" (1908). Shura. No. 4; 114-116.

Mansurov, G. (1927). Tatar provocateurs. M., p. 28-38.

Mardzhani, Sh. (1916). The 100th anniversary of his birthday. Kazan: 528.

Minnullin, Z. S. (1995). From the history of Tatar charitable societies of the late XIX - early XX centuries. Tatarstan. No. 11/12; 23-27.

Muhametdinov, R. F. (1996). The Origin and evolution of Turkism. Kazan: Zaman; 272 p.

Nasyri, Z. (1914). Tatar Muslims who study in Turkey. Time. July 27.

Russian Society for the promotion of the students-compatriots. 1913. 9 Nov.

Russian society of knowledge about Islam in Mecca (1910). Shura. No. 6; 191-192.

Russian society of knowledge about Medina in Kazan (1909). Star. September 8.

S. N. P. (1901). The Qur'an and progress. Tashkent: 246.

School of the Americas (1912). Time. 9 Mar.

Sibgatullin, A. T. (2010). Contacts of the Muslim Turks of the Russian and Ottoman empires at the turn of the XIX-XX centuries: In of Oriental studies; 264 p.

Tatar and Russian Muslim students in Istanbul (1908). Star. 7 Dec.

Tatar public organizations in Egypt (1906). Correspondent of Kazan. April 9; [in Egypt...]. Time. 1906. June 20.

Tatar society in Beirut (1914). Time. 22 January; "the Tatar community in Beirut". The Interpreter. (1914). 29 Jan.

The Report of the collegiate Secretary P. Antaki assigned to the Ministry of internal Affairs about his business trip to Cairo and Constantinople. RGIA, F. 821, op.133, d. 629, I. 65. 